\title{
The impacts of multiple large ownership structure on board independence
}

\author{
Ismail Adelopo* \\ University of the West of England, Frenchay Campus, \\ BS16 1QY, Bristol, UK \\ Email: Ismail.Adelopo@uwe.ac.uk \\ *Corresponding author
}

\section{Yinusa Ganiyu Olumuyiwa}

Department of Accounting, Banking and Finance,

Olabisi Onabanjo University,

Ago-Iwoye Ogun State, Nigeria

Email: yinusa2016@gmail.com

\section{Ibrahim Rufai}

Business School,

Staffordshire University,

Staffordshire, UK

Email: Ibrahim.Rufai@staffs.ac.uk

\begin{abstract}
The determinants of the composition of corporate boards remain inconclusive. This study investigates the impacts of multiple large ownership structure on board independence for a sample of UK listed companies. Using multiple regression analysis, and controlling for endogeneity, the study shows that the larger the difference in shareholding between the first and second largest owners, the less independent is the board. Monitoring efficiency is enhanced the higher the ratio of the shareholding of the second largest shareholder relative to the shareholding of the first largest shareholder. These findings have significant implications for board monitoring and corporate governance regulations.
\end{abstract}

Keywords: multiple large ownership structure; MLS; corporate governance; board independence.

Reference to this paper should be made as follows: Adelopo, I., Olumuyiwa, Y.G. and Rufai, I. (2019) 'The impacts of multiple large ownership structure on board independence', Int. J. Accounting, Auditing and Performance Evaluation, Vol. 15, No. 1, pp.1-30.

Biographical notes: Ismail Adelopo is a Chartered Accountant and Associate Professor of Accounting and Finance in the Faculty of Business and Law, UWE Bristol. His research interest focuses at the intersection of corporate governance accounting, auditing and financial management. 
Yinusa Ganiyu Olumuyiwa holds a PhD in Accounting and Finance from the De Montfort University and is a Lecturer with Olabisi Onabanjo University, Ago-Iwoye Ogun State Nigeria and currently works as a Research Fellow, National Institute for Legislative Studies, National Assembly, Abuja. His research interest centres around corporate governance and capital structure in firms.

Ibrahim Rufai graduated from the University of Birmingham with a $\mathrm{PhD}$ in Management, having previously worked as a senior banking executive in the financial services sector for some years and joined Staffordshire University in November 2015, as a Lecturer in Business and Management. His research interests are: SMEs and use of ICTs; corporate governance; supply chain management and business communications.

\section{Introduction}

This paper argues that the composition of the board of directors depends on the nature of interactions between large owners, i.e., whether owners act in coalition or they engage in ownership contest/rivalry. The corporate governance and recent financial crises continue to heighten regulators' concerns on board structure ${ }^{1}$ and the role of large owners in firms. Increasingly, the literature is recognising the impacts of ownership structure on the configuration of corporate boards. For example, in an extensive survey of literature, Adams et al. (2010) posed two fundamental questions regarding corporate boards. First, what determines their makeup and, secondly, what determines their actions? They argue that corporate boards are endogenously determined; meaning that their compositions depend on the governance issues confronted by the economic actor(s) concerned, i.e., owners. Furthermore, still focusing on what determines the makeup of corporate boards, Sur et al. (2013, p.374) argue that aggregated ownership configuration determines board composition. In their opinion, “owners' preferences map into individual directors' attributes that will collectively drive board composition". In other words, ownership type directly maps into individual director type, which ultimately determines the composition of the board.

Board functionality, which broadly falls between management monitoring and resources provision depends on the preferences of owners and their aggregated shareholding in the firm. Sur et al. (2013, p.374) argue that "insiders are more likely to be effective advisers to family owners/entrepreneurs, independent (outsider) directors may be in a better position to monitor management, while affiliated directors may be more effective in relaying a parent company's strategic intent". Similarly, Anderson and Reeb (2004) in a US study on mechanisms used to limit large owners' (especially family) expropriation of the firm, report a number of important results. Of relevance to this paper is the finding that family owners prefer to limit independent directors' presence on the board whilst outside large owners prefer more independent directors on the board. They argue that their findings highlight the importance of board independence in mitigating conflicts between large owners in a firm. 
These studies addressed important issues providing relevant answers to part of the puzzle regarding the determinants of the makeup of corporate boards. However, a lot remains unknown on this issue. For example, current literature has not considered the effects of the interactions between large owners on board composition. Rather than investigating the impact of aggregated ownership configuration on board composition, this study focuses on the nature and the consequences of the interactions between large owners in a firm for board composition. Whilst consideration of the impact of aggregated ownership configuration on board composition is clearly very important and partly addresses a situation where owners act in coalition, the realistic prospect of ownership contest or rivalry amongst large owners remains under researched. The extent of their ownership will fundamentally affect their interactions in the firm, and ultimately play a crucial part in determining the composition of the board.

Furthermore, recent literature has established the prevalence of multiple large ownership structure (MLS) in many European and North American corporations (Wang, 2017; Luo et al., 2013; McCahery et al., 2016; Edmans and Manso, 2009; Attig et al., 2008; Laeven and Levine, 2007; Kim et al., 2007; Gianfrate, 2007; Maury and Pajuste, 2005). MLS describes a situation, in listed firms, where there is more than one owner with substantial shareholding of a firm's issued share capital. These types of owners may not necessarily have dominant shareholding, but they have sufficient stake in a firm to attract regulatory attention and a statutory requirement for the disclosure of their identity and shareholding. ${ }^{2}$ Existing studies (Edmans and Manso, 2009; Holderness, 2009; Laeven and Lavine, 2007; Kim et al., 2007) argue that this type of shareholding configuration should enhance monitoring effectiveness on management. Yet literature evidence of the effects of this ownership type on board composition is scanty.

This investigation focuses on three linked questions that are particularly relevant to regulators' concerns on board independence and on the role of large investors in making the board more accountable. ${ }^{3}$ Firstly, does the presence of a MLS facilitate board independence or not? Secondly, what is the relationship between the size of the shareholding of the largest shareholder and board independence? Lastly, does the presence of a second largest shareholder in a MLS affect board independence?

In the UK, listed companies are required to disclose the shareholding and identity of shareholders with $3 \%$ or more of the issued shares of a company; such owners are often referred to as substantial or major shareholders in the annual reports of companies. This long-standing disclosure requirement provides an opportunity to examine the nature of interactions between large owners in a firm, and their effects on board structure in this context. This study adopts this ownership threshold in defining large owners. Edmans and Manso (2009) and Anderson and Reeb (2004) called for more studies to explore the monitoring roles of MLS (henceforth, MLS) and to understand the interactions between large owners in a firm. Using multiple regression models that control for firm specific characteristics and endogeneity problem on a sample of FTSE350 companies, this study responds to this call by examining the effects of MLS on board independence. 
This paper seeks to make a number of contributions to the literature. Firstly, this study extends the evidence in Attig et al.'s (2008) study on the effects of MLS on firms' cost of capital and Laeven and Levine's (2007) investigation into the effects of MLS on firm value. Thus, while they examined the impacts of MLS on cost of capital and firm value respectively, the focus of this study is on the effects of MLS on board independence. Consequently, this study contributes to the important debate on the determinants of an independent board. In this regard, this study provides additional answers to the question of what determines the makeup of corporate boards (Adams et al., 2010). The study argues that the interactions (i.e., coalition or contest) between large owners as well as the presence and the extent of share ownership of the second largest owner affect board composition. Specifically, the study reports a significant negative relationship between the largest shareholders, with a holding of at least $3 \%$ of the total number of issued ordinary shares of a firm, and board independence. The study also reveals that the higher the difference between the shareholding of the largest and the second largest shareholders the less independent the board becomes.

Secondly, the study contributes to the debate on the complementarity or otherwise of corporate governance mechanisms. The finding of a positive relationship between board independence and the relative shareholding of the second largest shareholder to the first largest shareholder supports Sur et al.'s (2013) conclusion that board and ownership structures of a firm play complementary not substitute roles in corporate governance. Findings from this study show that this complementary role is not limited to aggregated ownership configuration. The presence of a second large owner with at least $3 \%$ of the issued shares of a company could also facilitate complementary corporate governance mechanism leading to an independent board. This study shows that the efficacy of this monitoring role depends on the shareholding of the second largest shareholder relative to the shareholding of the largest shareholder.

Finally, this study provides evidence of the relationship between board independence and a MLS from a different context to the US, which dominates research in this area. Although both countries have similarities, especially in corporate institutional framework (Guest, 2008), their corporate governance mechanisms are profoundly different. For example, while the UK adopts broad principle approach to corporate governance, the US uses rule-based approach to corporate governance.

The remainder of the paper is structure as follows: Section 2 presents a background focusing on ownership structure, governance mechanisms and the UK corporate context. Section 3 presents the theoretical framework and Section 4 presents the empirical literature review and hypotheses development. Section 5 presents the research design, Section 6 presents the empirical results and discussion, and Section 7 presents the summary and conclusion.

\section{The UK corporate governance context: governance mechanisms and ownership structure}

Corporate governance is now a significant issue in the mainstream accounting and finance literature and the broader management disciplines (Al-Najjar, 2017; McCahery et al., 2016). The UK's corporate governance framework provided an important template for many global corporate governance reforms especially following the ENRON collapse at the turn of the 21st century. The Cadbury (1992) report was the precursor of the 
subsequent long list of corporate governance reports in the UK each of which now forms part of the integrated UK corporate governance code. It is customary to distinguish between the UK's principle based and US's rule-based approaches to corporate governance although the differences are more salient than the overly generalised distinction would suggest. According to Guest (2008, p.52) the UK has a distinctive corporate governance arrangement from the US for example, in the "enforcement of directors' legal duties, board structure and, the role of institutional investors and the nature of corporate governance reforms". It follows, therefore, that there are differences in the corporate governance mechanisms in both contexts and indeed in the UK compared to the continental European countries. For example, whilst the market for corporate control, as a feature of the external control mechanism, is very active in the US it is less so in the UK where incidences of merger and acquisitions and managerial discipline are not as pronounced (Solomon, 2010; Mallin, 2004). Nonetheless, the markets for corporate control and managerial discipline are more active in the UK compared to the continental European countries where there is overwhelming presence of insider ownership, mainly by banks, meaning that rather than having hostile takeovers and market imposed managerial discipline, internal arrangements are used to enforce desired corporate changes (Mallin, 2004).

One crucial internal corporate governance mechanism is the firms' ownership structure (McCahery et al., 2016). Solomon (2010) notes the dramatic change in the ownership structure of UK listed companies from individual and family ownership to more dominating role of institutional and large corporate owners. Whilst individual equity ownership has fallen from 54\% in 1963 to less than $18 \%$ in 1993 and $14 \%$ in 2002, institutional ownership has been on the increase, rising to approximately $62 \%$ in 1993 (Short and Keasey, 1999). This rise has been attributed to the growth in pension and insurance funds which have enjoyed increase in value as a result of the rise in private retirement savings from private pension schemes and long-term insurance policies. For instance, equity ownership by insurance companies increased from $10 \%$ in 1963 to $20 \%$ by 2002 . Similarly, equity ownership by pension fund companies increased from $6 \%$ in 1963 to $16 \%$ in 2002. Interestingly, there has also been increase in overseas shareholdings in the UK listed companies. This jumped from 7\% in 1963 to a significant $32 \%$ in 2002; most of the increases were due to increase in the holdings of institutional investors (Mallin, 2004).

However, given the size and nature of institutions' share ownership, it would be expected that they will play more active role in corporate governance in UK listed companies in line with the expectations of the Cadbury Report. Shleifer and Vishny (1986) also argued that institutional shareholders, by virtue of their large stake, would have incentives to monitor corporate performance since they have greater benefits through this monitoring and enjoy greater voting power that makes it easier to take corrective action when it is deemed necessary. Consistent with this active monitoring argument, Jarrell and Poulsen (1987) and Brickley et al. (1988) suggested that institutional shareholders are more likely to vote against harmful amendments that reduce shareholder wealth, while Agrawal and Mandelker (1990) found a positive relationship between institutional ownership and the shareholder wealth effects of various anti-takeover charter amendments. McConnell and Servaes (1990) found a positive relationship between institutional ownership and productivity, as measured by Tobin's Q. 
However, other studies have argued that institutional investors have limited incentives to monitor management actions. This could be because of free-riding among institutional investors making it difficult for them to take collective action (McCahery et al., 2016; Black, 1990; Admati et al., 1994). Furthermore, institutional investors may have incentives to sell their stocks in the face of poor performance rather than to initiate corrective actions (Coffee, 1991) in support of the absentee owners argument (Sykes, 1994).

In the UK, Faccio and Lasfer (2000) studied the impact of institutional investors in monitoring management. They compared the monitoring activities by pension funds owning more than $3 \%$ of issued share capital in organisations to a matched sample of those having less than a $3 \%$ stake and investigated their compliance with the Cadbury Code. They did not find any relationship between compliance with the code and institutional ownership. Similarly, they did not find any relationship between ownership concentration and firm performance. However, institutional investors are now playing more active roles in governance in listed companies (McCahery et al., 2016) through such organisations as the Association of British Insurers (ABI) and National Association of Pension Funds (NAPF). The next section presents the theoretical underpinning for this investigation.

\section{Theoretical framework}

Agency theory explains the structure, and justifies the importance of control mechanisms within the firm (Fama and Jensen, 1983; Fama, 1980; Eisenhardt, 1989; Jensen and Meckling, 1976). The separation of the control and ownership of the firm means that conflict of interests is inevitable due to self-interest and opportunistic behaviours by management (Bazerman et al., 1997). However, this problem is limited in jurisdictions with pronounced ownership concentration, because concentrated owners maintain closer control over management (Villalonga and Amit, 2006; Anderson and Reeb, 2004; Shleifer and Vishny, 1997) and their approach is different to that of absent owners in a more dispersed ownership structure (Shleifer and Vishny, 1997). Nonetheless, a concentrated ownership structure is also problematic (Dahya et al., 2008; Earle et al., 2005; Shleifer and Vishny, 1997) since such structure facilitates expropriation by major shareholders to the detriment of other shareholders (Ntim, 2013). This partly shifts the 'agency problem' from a conflict between owners and management to a conflict between different owners; those with large and those with small stakes in the organisation (Luo et al., 2013; Ntim, 2013; Holderness, 2009; Attig et al., 2008; Kim et al., 2007; Anderson and Reeb, 2004). Surprisingly, the literature is sparse in the consideration of the dynamics in the interactions amongst large owners. The interaction between owners is a very important issue that is capable of affecting strategic decisions about resource allocation in the firm. More importantly, the presence of more than one large owner could give rise to fundamental conflicts in determining the structure and composition of the board of directors, which is responsible for decisions about resource allocation, and the future directions of the firm (Hillman et al., 2000; Pearce and Zahra, 1992).

Unlike firms with a single large shareholder, where the composition of the board is most likely to be at this one shareholder's discretion, board composition in a MLS may be complicated (Wang, 2017). This study argues that, whether these owners are interested in shareholder value maximisation or in expropriation, the composition of the board will 
be crucial to the achievement of their objectives. Two or more large shareholders, however, have limited options. They could act in tandem to enforce an independent board that protects the interests of all shareholders or they could enforce a less independent board to facilitate expropriations from the firm. On the other hand, this ownership structure may lead to rivalry and disputes between large owners (Wang, 2017; Luo et al., 2013). In this case, the effects on board structure may be dependent on the level of ownership of each individual large owner compared to others. This study predicts that the larger the difference in the level of firm ownership among large owners, the lower the level of contests, as the largest shareholder controls the structure of the board. However, when the difference in their shareholdings is not large, the largest shareholder is less able to dominate the structure of the board. These important issues have so far received limited attention in the literature.

\section{Empirical literature and hypotheses development}

This section presents the empirical literature and motivates the hypotheses tested in the study based on agency theoretical framework.

\subsection{Concentrated ownership and board independence}

Conflict of interests arguments arising from the separation of ownership from management (Jensen and Meckling, 1976) make an independent board more likely in widely owned firms in order to protect the interests of numerous shareholders (Anderson and Reeb, 2004). However, when ownership becomes concentrated, large owners due to the scale of their investments, have the incentive and the resources to monitor management (McCahery et al., 2016; Cheng and Firth, 2005; Maug, 1998; McConnell and Servaes, 1990; Shleifer and Vishny, 1986). This additional monitoring may reduce the need for an independent board (Kim et al., 2007) for a number of reasons. Firstly, an independent board may be ineffective when not optimally constituted in terms of size and spread of expertise (Earle et al., 2005; Eisenberg et al., 1998; Yermack, 1996; Lipton and Lorsch, 1992); thereby adding more costs than benefits (Adams et al., 2010). Secondly, studies have shown that large owners enjoy special attention from management ( $\mathrm{Li}$ et al., 2012; Velury and Jenkins, 2006; Anderson and Reeb, 2004; Balsam et al., 2002) and have privileged access to important information (that is not necessarily insider information or that could be in breach of legislation) before other shareholders. These factors should enhance their monitoring role over management (McCahery et al., 2016). However, MLSs raise the free rider problem, which curtails large owners' monitoring incentive as they consider the cost-benefit trade-off of intervention (Shleifer and Vishny, 1986; Grossman and Hart, 1980). Jarrel and Poulson's (1987) analysis suggests that large owners may choose to be passive (Adams et al., 2010; Caplan, 2001; Magee et al., 1989), and this may make an independent board unlikely. However, firms with concentrated ownership may still have independent board due to regulatory requirements (Durnev and Kim, 2005; La Porta et al., 2002), or if they imitate industry norm. Consequently, the monitoring relevance of large owners is debatable.

The few existing studies on MLS suggest two possibilities. Firstly, MLS may form a coalition and collude to extract divisible private benefits (Wang, 2017; Attig et al., 2008; 
Dahya et al., 2008; Kim et al., 2007; Bennedsen and Wolfenzon, 2000) or, secondly, MLS can engage in control contests thereby making extraction of private benefits costly or impossible (Wang, 2017; Luo et al., 2013; Attig et al., 2008; Kim et al., 2007; Gomes and Novaes, 2006). This is because owners monitor one another. In the case of coalition, MLS would prefer a less independent board as this facilitates the extraction of divisible private benefits, the entrenchment argument (Luo et al., 2013). However, in the case of control contest, MLS would prefer an independent board to avoid the agency costs associated with disagreements and control contests (Attig et al., 2008; Earle et al., 2005), supporting the monitoring benefit argument of MLS (Wang, 2017; Luo et al., 2013). Thus, given the agency theoretical argument above and the extensive literature arguing that higher ownership concertation is consistent with expropriation of minority rights (Wang, 2017; Luo et al., 2013; Cheng and Firth, 2005; Maug, 1998; McConnell and Servaes, 1990; Shleifer and Vishny, 1986), the conjecture in this study is that MLS is increasing in firm concentration, meaning that higher number of large owners lead to higher ownership concentration. Consequently, we predict that this will lead to a less independent board. The majority of previous studies defined large ownership only with reference to their percentage shareholding. This study explores the monitoring effects of the number of large owners (Wang, 2017; Luo et al., 2013; Edmans and Manso, 2009; Koh, 2007; Maury and Pajuste, 2005) in addition to measuring ownership by percentage shareholding. Logically, the higher the number of large owners, the more concentrated the ownership of the firm. Therefore, this study predicts that, in such a situation, boards of directors will be less independent. Conversely, the lower the number of large owners, all things being equal, the less concentrated the firm. Therefore, this study predicts that this will lead to a more independent board of directors. Based on the arguments above, the first set of hypotheses are:

Hypothesis 1 Negative relationships exist between the number of all large owners and board independence.

Hypothesis 2 Negative relationships exist between the total percentage shareholding of all large owners and board independence.

\subsection{The largest owner and board independence}

When ownership concentration is high, the largest and rent seeking large owner will attempt to extract private benefits (Wang, 2017; Al-Bassam et al., 2015; Dahya et al., 2008; Earle et al., 2005; Cheng and Firth, 2005). If they can, they will influence the composition of the board in their favour so that they can extract private benefits at the expense of other shareholders (Wang, 2017; Attig et al., 2008; Dahya et al., 2008; Kim et al., 2007; Anderson and Reeb, 2004; Bennedsen and Wolfenzon, 2000). This would make such shareholders prefer a less independent board. This is in contrast to having an independent board, which is more likely to protect the interests of all shareholders (Anderson and Reeb, 2004; Rosenstein and Wyatt, 1997) by reducing the largest owners' opportunistic behaviour, since such behaviour will adversely affect firm value (La Porta et al., 2002). However, there are circumstances when even the largest shareholder may prefer an independent board. For example, Dahya et al. (2008) report the possibility that such shareholder may prefer to have an independent board in order to signal greater transparency to other outside investors, where the firm intends to raise capital. Doidge et al. (2004) argue that a dominant shareholder may commit to a higher corporate 
governance mechanism, for example, by preferring to list the firm's shares on an exchange with stronger shareholder protection and a more highly regulated environment. These make it costlier for the largest shareholder to divert the firm's resources and make an independent board more likely. Therefore, the literature (Dahya et al., 2008; Doidge et al., 2004) documents evidence of a potential positive relationship between ownership concentration and board independence although the majority of earlier studies suggest a negative relationship (Earle et al., 2005; Cheng and Firth, 2005; Shleifer and Vishny, 1997). Our theoretical prediction based on agency theory is that high ownership concentration (i.e., the presence of a large owner relative to other small owners) facilitates entrenchment and expropriation of private benefits (McCahery et al., 2016; Al-Bassam et al., 2015; Luo et al., 2013) through a less independent board. Our hypothesis is formally stated as:

Hypothesis 3 Negative relationships exist between the percentage shareholding of the largest owners and board independence.

\subsection{A second largest owner and board independence}

Studies have shown that, in firms with dominant shareholders, the presence of a second largest owner can constrain the ability of the dominant owner to extract private benefits because they can act as a check upon their activities (Wang, 2017; Bennedsen and Wolfenzon, 2000; Lehman and Weigand, 2000; Pagano and Roell, 1998). This may make an independent board more likely as large owners may mutually agree to bind themselves to a more stringent corporate governance mechanism, thereby avoiding a control contest. This will be the case where the difference in their percentage holding is not large (Attig et al., 2008). However, if the difference in their shareholdings is substantial, then it may become easier for the largest shareholder to exert greater influence on the composition of the board (Dahya et al., 2008) and they will most likely prefer a less independent board for the reasons discussed earlier.

On the other hand, in firms with two or more major large owners, the propensity for conflict of interest between these large owners is higher, since they are heterogeneous (Wang, 2017; Luo et al., 2013). However, prolonged disagreements between them could increase firm's agency costs of operation, a situation that is best avoided (Gomes and Novaes, 2006; Earle et al., 2005; Roe, 1990) because it could adversely affect firm value. Therefore, an independent board may be preferred to perform the required monitoring roles to avoid the adverse effects of a control contest and rivalry amongst large owners. Attig et al. (2008) find that the implied cost of capital is lower in firms with an MLS ownership structure. They suggest that the possibility of control contests may affect positively on the quality of firms' information and consequently on the cost of capital. This is because both owners monitor each other in an attempt to prevent the possibility of an extraction of unauthorised perquisites. Alternatively, large shareholders may act as a coalition to exploit minority shareholders and this is easier through a less independent board. An example is a situation where large owners prefer dividend pay-out as against the preference of capital appreciation by minority shareholders and vice versa.

Based on agency theoretical underpinning and prior discussions in this section, this study tests three hypotheses in this regard. In $\mathrm{H} 4$, the study examines the individual effect of the percentage shareholding of the second largest shareholder on board independence, and predicts a positive relationship between board independence and the presence of a 
second largest owner. In H5, the study examines the relative effect of the shareholding of the largest and the second largest shareholders on board independence, and predicts a positive relationship between the shareholding of the second largest owner relative to the shareholding of the largest shareholder and board independence. In H6, the study examines the effect of the difference in the shareholding of the largest and the second largest shareholders on board independence, and predicts a negative relationship between them. The hypotheses below reflect these situations:

Hypothesis 4 Positive relationships exist between the percentage shareholding of the second largest shareholder and board independence.

Hypothesis 5 Positive relationships exist between the relative shareholding of the second largest to the largest shareholder and board independence.

Hypothesis 6 Negative relationships exist between the difference in the shareholding of the largest and the second largest shareholders and board independence.

\section{Research design}

Firm ownership and governance are sticky and only change slowly depending on the economic environment; consequently this investigation is based on cross sectional analysis (Sur et al., 2013; Kaserer and Moldenhauer, 2008; Black et al., 2006). This study focused on the 2006-year end specifically to avoid the bias that may arise in using data in the financial crisis years, which covers 2007 upward. Erkens et al. (2012, p.390) argue that "independent directors pressured management to raise more equity capital during the financial crisis to ensure capital adequacy and reduce bankruptcy risk" thereby distorting firm ownership. The study uses data collected from the FAME ${ }^{4}$ database and the annual reports of sample companies to test the six hypotheses. The study uses data from the FAME database for firm specific variables such as firm size, complexity and profitability, and data from annual reports for corporate governance variables including ownership. The study used log transformations for some of the variables (for example, total assets and number of employees figures) and used the heteroscedasticity corrected robust standard error in all the regressions to enhance the reliability of reported results.

\subsection{Variable specification}

Board independence (BOIND) is the dependent variable, defined as the proportion of independent outside directors on the board divided by the total directors on it ( $\mathrm{Li}$ et al., 2012; Guest, 2008; Kim et al., 2007; Earle et al., 2005). The study divided the explanatory variables into three groups: firm ownership variables, corporate governance variables, and the control variables. The main ownership variables of concern are number of large shareholders (NLS), total percentage shareholding (TPS) by large shareholders, largest shareholder (LS), second largest shareholder (SLS), relative shareholding (RS), and the difference in shareholding (DS). NLS is the total number of shareholders with $3 \%$ or more of the shareholding of a company. Holderness (2009) argues that the NLS is important because it captures their monitoring intensity. This current study used $3 \%$ threshold based on our earlier explanation regarding statutory disclosure requirement in the UK. Using a lower threshold (3\%), as opposed to 5\% in Earle et al. (2005) or 10\% in 
Laeven and Levine (2007), reflects the dispersed ownership nature in the UK. TPS is the total of the shareholding by all disclosed large shareholders holding $3 \%$ or more of the issued shares in a company. This disclosure is a statutory requirement for all listed companies in the UK. LS defined the shareholder with the largest shareholding in the firm and SLS is the shareholder with the next largest shareholding after the LS, i.e., the SLS (Dahya et al., 2008; Earle et al., 2005). RS is the Ratio of the shareholding of the second largest to largest owner (Attig et al., 2008), and DS is the difference in shareholdings of largest and second largest owners in a firm (Laeven and Levine, 2007). The hypotheses above have identified the expected flow of relationship between these variables and our dependent variable.

Corporate governance variables are board size (BOSIZE) and board meetings (BOMET) respectively. The study included these variables because the effectiveness of the board's monitoring and oversight functions is dependent on its structure and functioning. The study left out audit committee and other ad-hoc board committees because previous studies argue that the overall functions of the board already incorporate their functions, as they are a subset of the main board (see Klein, 2002; Beasley, 1996). Studies have shown that large board size is indicative of boards' monitoring capacity and enhances skill diversity on the board (Yermack, 1996; Lipton and Lorsch, 1992). This study expects BOIND to be increasing in board size for this reason (Boone et al., 2007). BOSIZE is the total number of directors on the board. Furthermore, previous studies (Brick and Chidambaran, 2010; Anderson et al., 2004; Klein, 2002) used number of board meeting in a year to proxy for board diligence. Regular board meetings should enhance board's monitoring and oversight functions as they may allow the board the opportunity to deal with more board issues (Brick and Chidambaran, 2010). Boards that meet regularly are likely to be more effective than boards that meet less frequently. This study anticipates that BOIND is increasing in board meetings. BOMET is the total number of board meetings during the year. Consistent with previous studies, this study also used a variant of these variables for robustness, by taking their natural logarithms to give log BOSIZE and log BOMET respectively (Anderson et al., 2004; Klein, 2002; Carcello et al., 2002; Yermack, 1996).

The study controlled for several firm specific characteristics based on agency theoretical underpinning. Firm size is proxy by the log of total assets (Laeven and Levine, 2007; Karamanou and Vafeas, 2005) and by the log of the total number of employees (Earle et al., 2005). The study anticipates that larger firms will have greater monitoring and oversight need, and expects a positive relationship between BOIND and firm size. Firms' profitability is proxy by a dummy variable equal to 1 if a firm reports a profit in the last three years and 0 if otherwise (Whisenant et al., 2003). The link between BOIND and firm performance is ambiguous (Hermalin and Weisbach , 2003; Bhagat and Black, 2002), and the literature evidence gives conflicting results. However, the study anticipates that profitable companies would require less monitoring compared to loss making firms and therefore BOIND may be decreasing in firm performance as good performance may suggest less monitoring need (Vafeas, 1999). Similar explanation may be applicable to firms' efficiency in asset utilisation, proxy by return on assets employed (ROA), and defined as the ratio of profit before taxation and total capital employed in the period (Sur et al., 2013; Thomsen et al., 2006; Earle et al., 2005).

The study anticipates BOIND to be increasing in firm riskiness and complexity. So the more risky and complex a company is, the higher the need for an independent board 
in discharging monitoring and oversight functions. Firm risk is proxy by RISK, which is defined as total inventory plus receivables divided by total assets for the year (Lee and Mande, 2005; Whisenant et al., 2003). The study used two variables to proxy for firm complexity. The issue of pension cost and accounting remain highly contentious (Hann et al., 2007; Landsman and Ohlson, 1990) and captures the complexity of a firm. The study used the variable 'pension cost' as a dummy variable equal to 1 if a firm reports pension cost figures and 0 if otherwise (Whisenant et al., 2003). Exceptional (referred to as extraordinary item in US GAAP) item (EXCEP) is a dummy variable, equal to 1 if a firm reports an exceptional item in the year and 0 if otherwise (Knechel and Sharma, 2012). The study anticipates positive relationships between these measures of complexities and BOIND to reflect the higher monitoring requirements for such companies.

The study estimated several variants of the model below. In Table 1, the study presents the sample selection and industries representation, descriptive statistics, results and discussions of the regressions in Section 4. The sample comprised of non-financial and non-utility firms on the FTSE 350 companies. Companies in these two sectors were removed in keeping with the practice in the literature but also because they are subjected to additional regulations and different reporting requirements which could bias the overall results if they were included in the sample.

$$
\begin{aligned}
\text { BOIND } & =\beta_{1}+\beta_{2} \text { BOSIZE }+\beta_{3} B O M E T+\beta_{4} N L S+\beta_{5} T B S+\beta_{6} \text { LnAsset } \\
& +\beta_{7} \text { Profitability }+\beta_{8} R O A+\beta_{9} \text { RISK }+\beta_{10} \text { Pension } \cos t \\
& +\beta_{11} \text { EXCEP }+\varepsilon
\end{aligned}
$$

Table 1 Sample selection

\begin{tabular}{lc}
\hline & Number \\
\hline Total companies in the FTSE350 & 350 \\
Exclude: Investment trust companies & 36 \\
$\quad$ Financial companies: with SIC number 6511-6713 & 76 \\
Utility companies: with SIC number 4011-4100 & 9 \\
Companies with missing data & 20 \\
Total number of companies in the final sample & 209 \\
\hline
\end{tabular}

\section{Empirical result and discussions}

\subsection{Descriptive statistics}

Table 2 presents the descriptive statistics for all the variables. The average board is composed of approximately 50\% independent directors. This is consistent with findings in Wang and Hussainey (2013) who reported 51\% BOIND in a study of the impact of corporate governance on voluntary forward-looking statements disclosure for a sample of UK companies in a similar period. 
Table 2 Descriptive statistics

\begin{tabular}{lccccc}
\hline Variables & Mean & Std. dev & Min & Median & Max \\
\hline BOIND & 0.50 & 1.70 & .25 & 0.50 & .83 \\
BOSIZE & 9.44 & 2.18 & 5 & 9.00 & 18 \\
BOMET & 8.28 & 2.58 & 1 & 8.00 & 15 \\
NLS & 4.71 & 2.29 & 0 & 4.00 & 12 \\
TPS & 31.54 & 16.82 & 3.72 & 29.8 & 92.10 \\
LS & 19.33 & 12.66 & 4.92 & 17.02 & 92.10 \\
SLS & 12.64 & 10.05 & 3.00 & 10.35 & 62.80 \\
RS & 0.64 & 0.15 & 0.61 & 0.60 & 0.71 \\
DS & 6.71 & 4.27 & 0.72 & 5.90 & 29.30 \\
LnAsset & 14.24 & 1.79 & 3.912 & 14.17 & 20.64 \\
LnEmploy & 8.59 & 1.96 & 2.71 & 8.96 & 12.92 \\
Profitability & 0.95 & 0.23 & 0 & 1.00 & 1.00 \\
ROA & 16.20 & 17.45 & -44.56 & 12.93 & 106.74 \\
RISK & 0.13 & 0.13 & 0.00 & 0.09 & 0.98 \\
Pension & 0.92 & 0.28 & 0 & 1.00 & 1 \\
EXCEP & 0.20 & 0.40 & 0 & 1.00 & 1 \\
\hline
\end{tabular}

Notes: BOIND is board independence; defined as the proportion of independent directors to total directors on the board. BOSIZE is board size; defined as the total number of directors on the board. BOMET is board meeting; defined as the total number of meetings held in a year. NLS is number of large shareholders with at least $3 \%$ of the total shareholding in a firm. TPS is total percentage shareholding of all shareholders with at least $3 \%$ of the total shareholdings in a firm. LS is largest shareholder and is the shareholder with the highest shareholding in a firm. SLS is the second largest shareholder and is the shareholder with the next largest shareholdings in a firm. RS is the ratio of shareholding and is the ratio of the shareholding of the second largest to the largest shareholder. DS is the difference in shareholding and is difference between the shareholding of the largest to the second largest shareholder. LnAsset is the log of total asset and proxy for firm size. LnEmploy is the log of total number of employees and proxy for firm size. Profitability is a dummy variable, 1 if firm reports profit in the last three years and 0 if otherwise. ROA is return on assets and is a proxy for firm efficiency in asset utilisation; defined as the ratio of total profit before tax divided by capital employed. RISK proxy for firm riskiness and is the sum of total inventory and receivables divided by total asset. Pension is a measure of complexities and it is 1 if a firm reports pension cost figures and 0 if otherwise. EXCEP is a measure of complexities and it is 1 if a firm reports exceptional item in the year and 0 if otherwise.

Similarly, Li et al. $(2008,2012)$ both reported an average of $48 \%$ and $47 \%$ BOIND respectively in their UK studies of the effects of corporate governance on intellectual capital disclosures. However, this is in contrast to Kim et al. (2007) who in their crosscountry analysis of the relationship between large shareholders, BOIND and minority shareholder right reported an average of $75 \%$ BOIND for their UK sample. Their high average BOIND figure may have been driven by their sample selection, which concentrates only on large firms and their small sample size. The average board in our sample has nine directors compared to eight directors reported in Wang and Hussainey (2013). The smallest board has five directors while the largest board has 18 directors. The average (median) board had eight meetings during the year. On average, firms in the 
sample have five MLS each holding at least 3\% of the issued ordinary share capital of the firm, the median number of MLS was four. The average (median) TPS of all LS for the firms in the sample was $32 \%(30 \%)$. This is consistent with the reported figures in Li et al. (2008) who reported an average cumulative of $30 \%$ and a median of $26 \%$. The average (median) total shareholding of the LS for the firms in the sample was $19 \%(17 \%)$ while the average (median) shareholding for the SLS was 13\% (10\%).

Table 3 Correlation matrix for variables used in the study

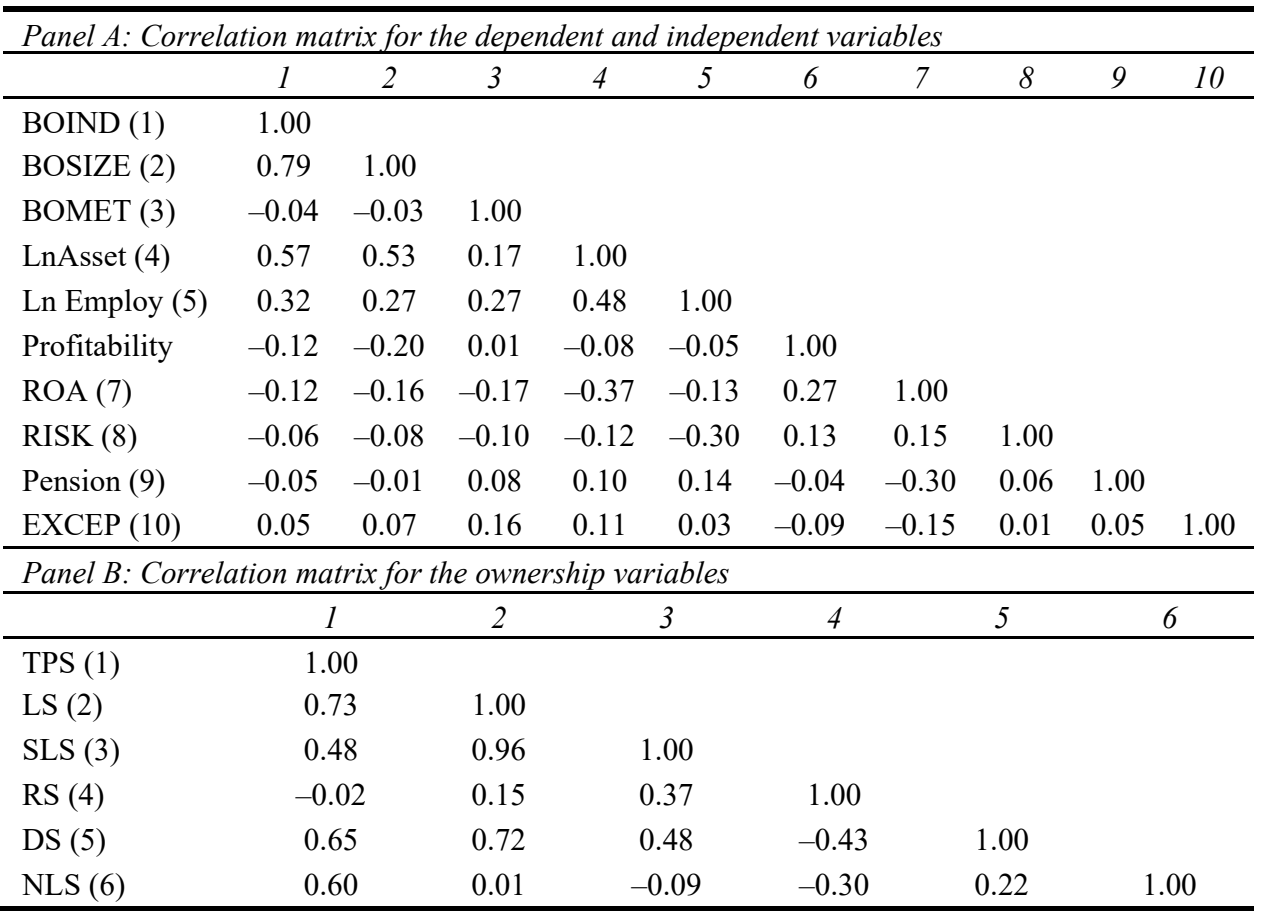

Notes: BOIND is board independence; defined as the proportion of independent directors to total directors on the board. BOSIZE is board size; defined as the total number of directors on the board. BOMET is board meeting; defined as the total number of meetings held in a year. NLS is number of large shareholders with at least $3 \%$ of the total shareholding in a firm. TPS is total percentage shareholding of all shareholders with at least $3 \%$ of the total shareholdings in a firm. LS is largest shareholder and is the shareholder with the highest shareholding in a firm. SLS is the second largest shareholder and is the shareholder with the next largest shareholdings in a firm. RS is the ratio of shareholding and is the ratio of the shareholding of the second largest to the largest shareholder. DS is the difference in shareholding and is difference between the shareholding of the largest to the second largest shareholder. LnAsset is the log of total asset and proxy for firm size. LnEmploy is the log of total number of employees and proxy for firm size. Profitability is a dummy variable, 1 if firm reports profit in the last three years and 0 if otherwise. ROA is return on assets and is a proxy for firm efficiency in asset utilization; defined as the ratio of total profit before tax divided by capital employed. RISK proxy for firm riskiness and is the sum of total inventory and receivables divided by total asset. Pension is a measure of complexities and it is 1 if a firm reports pension cost figures and 0 if otherwise. EXCEP is a measure of complexities and it is 1 if a firm reports exceptional item in the year and 0 if otherwise. 
Table 3 presents the correlation matrix for all the variables. Panel A shows the correlation matrix for all the variables except the ownership variables. None of the correlations is above the threshold of 0.80 (Li et al., 2008, 2012). Panel B shows the correlation matrix for the ownership variables. Whilst there are a number of high correlations between some of the ownership variables, variance inflation factor (VIF) showed that, there is no serious multicollinearity problem in our regressions. The average VIF for our entire sample was 1.36 and none of the variables was close to the threshold of 10 (Hair et al., 2010; Li et al., 2008). Furthermore, as a precaution, the study did not use highly correlated variables in the same regression.

\subsection{Regression results}

The study presents the regression results of six models in Table 4. Model 1 shows the regression results of the dependent variable; BOIND, on the corporate governance variables, one ownership variable; NLS and the firms' control variables. BOSIZE showed a significant positive (coeff: 0.54 ; t-stat: 13.05) relationship with BOIND, but the ownership variable was not significant. In terms of the control variables, firm size (log total asset) showed a significant positive $(0.25 ; 2.76)$ relationship with BOIND, consistent with the argument in Lehn et al. (2004) that large firms have more independent boards. This may be because they are likely to have higher agency problems and therefore higher monitoring need. Measures of firm performance (profitability, ROA), RISK and firm complexity (EXCEP) were not significant, although pension, an alternative measure of complexity, showed a significant negative $(-0.44 ;-2.40)$ relationship with BOIND, conflicting with the findings in Whisenant et al. (2003) who found a positive relationship although their study was on audit pricing.

Model 2 presents the results of the regression with ownership variables based on the TPS by LSs with at least 3\% of the firms' issued ordinary shares. The results are identical to the results from model 1. Thus, the results from models 1 and 2 do not support Hypotheses 1 and 2, and so this study concludes that there is no relationship between the numbers of LSs, TPS of the LSs owning at least $3 \%$ of the firms' issued ordinary shares and BOIND. These findings are consistent with the argument that the relationship between ownership concentration and BOIND is ambiguous and complicated. Sur et al. (2013) also report lack of significant relationship between institutional ownership and BOIND. The findings may also indicate the importance of investigating specific characteristics of ownership such as the ownership by largest and second largest owners rather than assuming that all large owners are homogenous. Model 3 presents the results of the regression with ownership variables based on the shareholding by the LS with at least 3\% of the firms' issued ordinary share capital. Hypothesis 3 tests this relationship. The study finds a significant negative relationship at $5 \%$ level between the shareholding of the LS and BOIND $(-0.05 ;-2.40)$. This is consistent with the theoretical expectations in this study and the general perception in the literature (Dahya et al., 2008; Earle et al., 2005; Cheng and Firth, 2005). The result indicates that the higher the percentage shareholding of the LS with at least $3 \%$ of the issued share capital in a company, the less independent the board is likely to be. This supports the conjecture that the LS prefers a less independent board for the reasons outlined above (Attig et al., 2008; Dahya et al., 2008; Kim et al., 2007; Bennedsen and Wolfenzon, 2000). This finding supports 
hypothesis $\mathrm{H} 3$ that a negative relationship exists between the shareholding of the LS and BOIND.

Table 4 Regression results - dependent variable: BOIND

\begin{tabular}{|c|c|c|c|c|c|c|}
\hline & Model 1 & Model 2 & Model 3 & Model 4 & Model 5 & Model 6 \\
\hline BOSIZE & $\begin{array}{c}0.54 \\
13.05^{* * *}\end{array}$ & $\begin{array}{c}0.53 \\
13.35^{* * *}\end{array}$ & $\begin{array}{c}0.54 \\
13.24^{* * *}\end{array}$ & $\begin{array}{c}0.54 \\
13.92 * * *\end{array}$ & $\begin{array}{c}0.54 \\
13.64 * * *\end{array}$ & $\begin{array}{c}0.55 \\
13.88 * * *\end{array}$ \\
\hline BOMET & $\begin{array}{l}-0.03 \\
-1.13\end{array}$ & $\begin{array}{l}-0.03 \\
-1.08\end{array}$ & $\begin{array}{c}0.02 \\
-0.71\end{array}$ & $\begin{array}{l}-0.03 \\
-1.05\end{array}$ & $\begin{array}{l}-0.02 \\
-0.66\end{array}$ & $\begin{array}{l}-0.19 \\
-0.72\end{array}$ \\
\hline NLS & $\begin{array}{l}0.01 \\
0.06\end{array}$ & & & & & \\
\hline TPS & & $\begin{array}{l}0.01 \\
1.38\end{array}$ & & & & \\
\hline LS & & & $\begin{array}{c}-0.05 \\
-2.40 * *\end{array}$ & & & \\
\hline SLS & & & & $\begin{array}{c}0.06 \\
2.48 * *\end{array}$ & & \\
\hline $\mathrm{RS}$ & & & & & $\begin{array}{c}1.12 \\
2.80 * *\end{array}$ & \\
\hline DS & & & & & & $\begin{array}{c}-0.04 \\
-2.14 * *\end{array}$ \\
\hline LnAsset & $\begin{array}{c}0.25 \\
2.76^{* *}\end{array}$ & $\begin{array}{c}0.25 \\
2.79 * *\end{array}$ & $\begin{array}{c}0.28 \\
3.38 * * *\end{array}$ & $\begin{array}{c}0.23 \\
2.48 * *\end{array}$ & $\begin{array}{c}0.25 \\
3.09 * * *\end{array}$ & $\begin{array}{c}0.28 \\
3.27^{* * *}\end{array}$ \\
\hline Profitability & $\begin{array}{l}0.29 \\
0.57\end{array}$ & $\begin{array}{l}0.21 \\
0.42\end{array}$ & $\begin{array}{l}0.22 \\
0.45\end{array}$ & $\begin{array}{l}0.20 \\
0.39\end{array}$ & $\begin{array}{l}0.22 \\
0.45\end{array}$ & $\begin{array}{l}0.10 \\
0.21\end{array}$ \\
\hline ROA & $\begin{array}{l}0.01 \\
0.84\end{array}$ & $\begin{array}{l}0.01 \\
0.75\end{array}$ & $\begin{array}{l}0.01 \\
1.02\end{array}$ & $\begin{array}{l}0.01 \\
0.71\end{array}$ & $\begin{array}{l}0.01 \\
0.97\end{array}$ & $\begin{array}{l}0.01 \\
1.20\end{array}$ \\
\hline
\end{tabular}

Notes: BOIND is board independence; defined as the proportion of independent directors to total directors on the board. BOSIZE is board size; defined as the total number of directors on the board. BOMET is board meeting; defined as the total number of meetings held in a year. NLS is number of large shareholders with at least 3\% of the total shareholding in a firm. TPS is total percentage shareholding of all shareholders with at least 3\% of the total shareholdings in a firm. LS is largest shareholder and is the shareholder with the highest shareholding in a firm. SLS is the second largest shareholder and is the shareholder with the next largest shareholdings in a firm. RS is the ratio of shareholding and is the ratio of the shareholding of the second largest to the largest shareholder. DS is the difference in shareholding and is difference between the shareholding of the largest to the second largest shareholder. LnAsset is the log of total asset and proxy for firm size. LnEmploy is the log of total number of employees and proxy for firm size. Profitability is a dummy variable, 1 if firm reports profit in the last three years and 0 if otherwise. ROA is return on assets and is a proxy for firm efficiency in asset utilization; defined as the ratio of total profit before tax divided by capital employed. RISK proxy for firm riskiness and is the sum of total inventory and receivables divided by total asset. Pension is a measure of complexities and it is 1 if a firm reports pension cost figures and 0 if otherwise. EXCEP is a measure of complexities and it is 1 if a firm reports exceptional item in the year and 0 if otherwise. $*=$ significant at 0.1 level, i.e., $\mathrm{p}<0.10 ; * *=$ significance at 0.05 level, i.e., $\mathrm{p}<0.05 ; * * *=$ significance at 0.01 level, i.e., $\mathrm{p}<0.01$. 
The impacts of multiple large ownership structure on board independence

Table 4 Regression results - dependent variable: BOIND (continued)

\begin{tabular}{lcccccc}
\hline & Model 1 & Model 2 & Model 3 & Model 4 & Model 5 & Model 6 \\
\hline RISK & 0.08 & 0.04 & 0.20 & 0.05 & 0.20 & 0.27 \\
& 0.11 & 0.05 & 0.27 & 0.07 & 0.26 & 0.35 \\
Pension & -0.44 & -0.46 & -0.30 & -0.40 & -0.23 & -0.29 \\
& $-2.04^{* *}$ & $-2.39^{* *}$ & -1.22 & $-1.97^{* *}$ & -0.92 & -1.22 \\
EXCEP & -0.01 & -0.02 & -0.02 & -0.05 & -0.04 & -0.01 \\
& -0.07 & -0.16 & -0.27 & -0.31 & -0.29 & -0.07 \\
Intercept & -4.20 & -4.02 & -4.21 & -3.77 & -4.55 & -4.28 \\
& $-3.30^{* * *}$ & $-3.21^{* *}$ & $-3.52^{* * *}$ & $-3.05^{* *}$ & $-3.64^{* * *}$ & $-3.37^{* * *}$ \\
Adj $R$ & 0.69 & 0.68 & 0.68 & 0.69 & 0.68 & 0.68 \\
$N=209$ & & & & & & \\
\hline
\end{tabular}

Notes: BOIND is board independence; defined as the proportion of independent directors to total directors on the board. BOSIZE is board size; defined as the total number of directors on the board. BOMET is board meeting; defined as the total number of meetings held in a year. NLS is number of large shareholders with at least $3 \%$ of the total shareholding in a firm. TPS is total percentage shareholding of all shareholders with at least $3 \%$ of the total shareholdings in a firm. LS is largest shareholder and is the shareholder with the highest shareholding in a firm. SLS is the second largest shareholder and is the shareholder with the next largest shareholdings in a firm. RS is the ratio of shareholding and is the ratio of the shareholding of the second largest to the largest shareholder. DS is the difference in shareholding and is difference between the shareholding of the largest to the second largest shareholder. LnAsset is the log of total asset and proxy for firm size. LnEmploy is the log of total number of employees and proxy for firm size. Profitability is a dummy variable, 1 if firm reports profit in the last three years and 0 if otherwise. ROA is return on assets and is a proxy for firm efficiency in asset utilization; defined as the ratio of total profit before tax divided by capital employed. RISK proxy for firm riskiness and is the sum of total inventory and receivables divided by total asset. Pension is a measure of complexities and it is 1 if a firm reports pension cost figures and 0 if otherwise. EXCEP is a measure of complexities and it is 1 if a firm reports exceptional item in the year and 0 if otherwise. $*=$ significant at 0.1 level, i.e., $\mathrm{p}<0.10 ; * *=$ significance at 0.05 level, i.e., $\mathrm{p}<0.05 ; * * *$ significance at 0.01 level, i.e., $\mathrm{p}<0.01$.

Furthermore, the result in model 4 shows a significant positive $(0.06 ; 2.48)$ relationship between the SLSs and BOIND at the 5\% level. This indicates that the higher the percentage shareholding of the SLS with at least $3 \%$ of the issued ordinary share capital of a firm, the more independent the board is likely to be. This result supports Hypothesis $\mathrm{H} 4$ that a positive relationship exists between the percentage shareholding of the SLS and BOIND. While models 3 and 4 examined the individual effects of the shareholding of the LS and SLS on BOIND, models 5 and 6 present the results of the hypotheses testing for Hypotheses 5 and 6. First, in Hypothesis 5, the study used the ratio of the shareholding of the second largest to the largest owner. Secondly, in Hypothesis 6, the study used the difference between the percentage shareholding of the LS and the SLS. As explained in Section 3, the study anticipates that the higher the shareholding of the SLS relative to the shareholding of the LS, the higher the possibility of an independent board. This is because the SLS can act as a check on the activity of the LS. They may eventually bind themselves to a higher governance mechanism to avoid the negative effects of control contest. In model 5, the study presents the results of the relative effects of these 
shareholdings on BOIND. The coefficient of this relationship showed a positive and statistically significant relationship at $5 \%$ level with BOIND $(1.12 ; 2.80)$. This supports the study's prediction and shows that the SLS constrains the LS and this could be an example of a situation where they both bind themselves to a superior governance structure. It also indicates a situation where the SLS constitute a check on the LS. Consequently, the result supports Hypothesis 5 that suggests that the higher the ratio of the shareholding of the SLS to the LS the more independent the board becomes.

In model 6, the study presents the results of the regression that tests Hypothesis 6. Consistent with the study's prediction, the difference between the shareholdings of the largest and second largest owners shows a significant negative $(-0.04 ;-2.14)$ relationship with BOIND at the $5 \%$ level. The result supports the conjecture that the higher the DS of the LS and the SLS, the less independent the board becomes. This result indicates that gaps in shareholding of the first LS relative to the shareholding of the SLS constitute additional control for the LS. Such control could be instrumental in the decision about board composition. If the largest owner is interested in opportunistic behaviour, they will use their ownership control to influence the composition of the board and will most likely prefer a less independent board. This is because a less independent board makes extraction of private benefit less costly compared to an independent board which seeks to protect the interests of all shareholders; those with large and small stakes in the firm.

\subsection{Discussion}

This paper explores the impact of a MLS on BOIND for a sample of UK listed companies for the financial year ending in 2006. The paper focused on the nature of the interactions between large owners and their effects on BOIND. The paper finds a very strong and robust influence of MLS on BOIND as consistent with Hypotheses 3, 4, 5 and 6. The paper finds a significant negative relationship between a single LS and BOIND. This suggests that, in the absence of other owners with a significant shareholding, the single LS will most likely favour a less independent board. This is consistent with the findings in Wang (2017) which suggest that the large owner will pursue private benefits at the expensive of smaller owners. This is also consistent with the idea that the LS face a unique utility function (risk v return issues) that influences their actions. For example, even when single dominant shareholders signal transparency through voluntary commitment to more value enhancing corporate governance practices, the fact that such practices are at their sole discretion may make them less credible (Dahya et al., 2008).

However, in a MLS depending, inter alia, on the extent of the differences in shareholdings between LSs, the LS is in competition with other LSs and their heterogeneous incentives (Wang, 2017). This is because large owners, individually, face their own unique utility function, which they seek to maximise. Therefore, LSs can cooperate by forming a coalition (Luo et al., 2013; Gianfrate, 2007) or they may resort to a control contest. Corporate governance researchers and policy makers may be more concerned with the prospect of a control contest between multiple large owners than the prospect of a coalition. This is due to the potential for control contest ${ }^{5}$ to facilitate value enhancing corporate governance practices. For example, Dahya et al.'s (2008) finding of the influence of MLSs on reducing firms' cost of capital complements the competition rather than the coalition hypothesis. Similarly, Wang (2017) findings show that competition between large owners could benefit smaller owners in the context of cumulative voting. Findings from this study reinforce the perception in the literature 
(Wang, 2017; Gomes and Novaes, 2006; Maury and Pajuste, 2005; Anderson and Reeb, 2004) that a control contest between large owners benefits minority shareholders. In this case, by leading to more independent board which, all things being equal, should lead to greater corporate accountability to the extent that it prevents extraction of divisible private benefits.

Findings from this study are of practical importance to policy makers and market regulators who continue to search for new ways of enhancing the efficiency of the current corporate governance mechanisms. This is because findings from this study provide a direction for policy makers in which to search for alternative ownership mechanisms that can facilitate higher value enhancing corporate governance systems in corporations. In this case, findings from this study is consistent with Sur et al.'s (2013) argument that board and ownership structures act as complementary rather than substituting corporate governance mechanisms. However, the extent of their complementarity is not homogenous and cannot be pre-determined because they depend on each firm's unique circumstances. Findings from this study also complement arguments in previous studies such as Ward et al. (2009) and Rediker and Seth (1995) regarding corporate governance bundles, which suggest that firms depend on a bundle of corporate governance mechanisms and that the selection of these bundles is firm specific, and cannot be generalised. Thus, a firm's corporate governance mechanism is an integrated and interlinked array of governance procedures (Ward et al., 2009; Aguilera et al., 2008; Rediker and Seth, 1995). Thus, "one size does not fit all".

The finding from this study of a positive relationship between the shareholding of the SLS and BOIND, combined with the results of testing Hypotheses 5 and 6, reinforce the argument that the presence of more LSs should enhance the monitoring roles of the large owners acting together in competition. This is consistent with the suggestions in Earle et al. (2005) who found that the marginal value of additional concentration is either zero or negative if it arises from an increase in the number of secondary large owners. This is to the extent that they seek an optimal number of LSs. However, this study focused on the monitoring influence of the presence and the extent of ownership of the second largest owner. Findings from this study supports the argument that concentration has costs and benefits, but that concentration through multiple large ownerships could lead to a more balanced board, which could prevent private diversion of firm resources by the dominant single large owner. This type of ownership structure could resolve collective action problems or costs of disagreement (stepping on each other's toes and reduced share liquidity) through an independent board. Findings from this study show that the presence of a second large owner moderates the effects of the LS to sustain a less independent board (Luo et al., 2013). Hypothesis 6 shows that the higher the difference between the shareholding of the first and second LSs the less independent the board becomes.

\subsection{Robustness check}

\subsubsection{Endogeneity concerns}

The study undertakes a number of additional tests to enhance the rigour of reported results. First, previous studies observe that accounting and governance research are prone to endogeneity ${ }^{6}$ problems (Carcello et al., 2011; Larcker and Rusticus, 2007, 2010; Chenhall and Moers, 2007). This makes checking for endogeneity an important issue in empirical investigations. Adkins and Hill (2011, p.332) provide both theoretical and 
practical explanations of how to conduct the Hausman test for endogeneity using econometric software. ${ }^{7}$ This study suspects the existence of correlation between firm ownership and unexplained omitted variables in the error term. This implies potential correlation between the error terms and BOIND. If this is the case, the model specification will not be appropriate. A popular approach to handling endogeneity problem is instrumental variable or the two stage least squares approach (2SLS). ${ }^{8}$ However, a formidable challenge remains identifying suitable instrumental variables (see Larcker and Rusticus, 2007, 2010). In view of this difficulty, studies (Larcker and Rusticus, 2007; Hentschel and Kothari, 2001) have suggested the use of reasonable crude measures as instruments since it is almost impossible to find a perfect instrument. Consequently, this study used ownership rankings as instrumental variables.

Ownership ranking, in this study, is the ranked sum of the shareholdings of all disclosed large owners (which is the same as our TPS). ${ }^{9}$ The study refers to this instrumental variable as RANK. Ownership rank is likely to be correlated with TPS $[\operatorname{cov}(X, Z) \neq 0]$ but unlikely to be correlated with the error term or other unexplained variables in the error term $[\operatorname{cov}(Z, U)=0]$ which may affect our dependent variable. To conduct the test, the study runs a regression of TPS on RANK and other exogenous variables in the model. The study then obtained the predicted value of the residuals (uhat) from this regression which is then added to the original model specification used in model 2 in Table 4 . The study used model 2 because it is based on TPS. Using t-test, the study tested whether the coefficient of RANK is different from zero or not. If the coefficient of RANK is zero [ $\operatorname{cov}($ RANK, $u)=0$ ] this rules out endogeniety in the model, otherwise OLS will produce bias results. First, the study established through correlation analysis (result not tabulated) that TPS and RANK are highly correlated at 0.84 . This is an important necessary condition for a suitable instrument. Table 5 below reports the results of the endogeneity test. Model 7 in Table 5 reports the first stage regression and model 8 reports the second stage regression results in the test. In model 7, RANK is the variable of concern and it shows a significant positive relationship with TPS $(0.16 ; 13.68)$ at $1 \%$ level. In the second stage regression (model 8$)$, uhat is the variable of concern and is not significant $(0.01 ; 0.15)$ at any of the conventional level, and this confirms that endogeneity is not a problem in this instance. The study performed similar checks for each of the models reported in Table 4 ruling out endogeneity in all.

\subsubsection{Alternative measure of board size, board meeting frequency and firm size}

To enhance the robustness of the reported findings further, the study introduced a number of variations into the models. First, consistent with previous studies (Carcello et al., 2002; Anderson et al., 2004), the study used the natural logarithm of the corporate governance variables, i.e., $\log$ of board size and $\log$ of board meeting. As can be seen from Table 6 below, the results are identical with the reported results in Table 4. Importantly, models $10-13$ in Table 6 are identical to models $3-6$ in Table 4 . These results support the initial findings of significant impact that the presence of a second large owners could have on the composition of the board given the shareholding of the LS. Secondly, the study also checked the robustness of the results to alternative definition of firm size using natural $\log$ of the total number of employees (Earle et al., 2005). The results remain largely unchanged. LnEmployee showed significant positive relationship with BOIND and confirms previous results reported in Table 4. 
Table 5 Endogeneity check

\begin{tabular}{|c|c|c|}
\hline & Mode7 (TPS) & Model 8 (BOIND) \\
\hline BOSIZE & $\begin{array}{l}0.28 \\
1.11\end{array}$ & $\begin{array}{c}0.56 \\
13.40^{* * *}\end{array}$ \\
\hline BOMET & $\begin{array}{l}0.05 \\
0.30\end{array}$ & $\begin{array}{l}-0.01 \\
-0.58\end{array}$ \\
\hline TPS & & $\begin{array}{l}0.04 \\
0.73\end{array}$ \\
\hline RANK & $\begin{array}{c}0.16 \\
13.68^{* * *}\end{array}$ & \\
\hline LnAsset & $\begin{array}{c}0.61 \\
1.93 * *\end{array}$ & $\begin{array}{c}0.19 \\
2.39 * * *\end{array}$ \\
\hline Profitability & $\begin{array}{l}-3.43 \\
-0.82\end{array}$ & $\begin{array}{l}-0.11 \\
-0.20\end{array}$ \\
\hline ROA & $\begin{array}{l}0.02 \\
1.06\end{array}$ & $\begin{array}{l}0.01 \\
0.85\end{array}$ \\
\hline RISK & $\begin{array}{l}-2.82 \\
-1.22\end{array}$ & $\begin{array}{l}0.05 \\
0.10\end{array}$ \\
\hline Pension & $\begin{array}{l}-1.06 \\
-0.32\end{array}$ & $\begin{array}{l}-0.27 \\
-1.19\end{array}$ \\
\hline EXCEP & $\begin{array}{l}-1.49 \\
-1.74 *\end{array}$ & $\begin{array}{l}-0.01 \\
-0.08\end{array}$ \\
\hline uhat & & $\begin{array}{l}0.01 \\
0.15\end{array}$ \\
\hline Intercept & $\begin{array}{l}-6.28 \\
-1.20\end{array}$ & $\begin{array}{c}-3.10 \\
-2.39^{* * *}\end{array}$ \\
\hline $\begin{array}{l}\text { Adj } R \\
N=209\end{array}$ & 0.72 & 0.66 \\
\hline
\end{tabular}

Notes: BOIND is board independence; defined as the proportion of independent directors to total directors on the board. BOSIZE is board size; defined as the total number of directors on the board. BOMET is board meeting; defined as the total number of meetings held in a year. TPS is total percentage shareholding of all shareholders with at least $3 \%$ of the total shareholdings in a firm. RANK is the instrumental variable and it is the rank of TPS in ascending order. LnAsset is the $\log$ of total asset and proxy for firm size. Profitability is a dummy variable, 1 if firm reports profit in the last three years and 0 if otherwise. ROA is return on assets and is a proxy for firm efficiency in asset utilisation; defined as the ratio of total profit before tax divided by capital employed. RISK proxy for firm riskiness and is the sum of total inventory and receivables divided by total asset. Pension is a measure of complexities and it is 1 if a firm reports pension cost figures and 0 if otherwise. EXCEP is a measure of complexities and it is 1 if a firm reports exceptional item in the year and 0 if otherwise. uhat is the predicted value of the residual from the first stage regression, and represents the correlations between the instrumental variable and the error term. $*=$ significant at 0.1 level, i.e., $p<0.10$; $* *=$ significance at 0.05 level, i.e., $\mathrm{p}<0.05 ; * * *=$ significance at 0.01 level, i.e., $\mathrm{p}<0.01$ 
Table 6 Regression results - dependent variable: BOIND

\begin{tabular}{|c|c|c|c|c|c|}
\hline & Model 9 & Model 10 & Model 11 & Model 12 & Model 13 \\
\hline LnBOSIZE & $\begin{array}{c}4.97 \\
11.64 * * *\end{array}$ & $\begin{array}{c}4.98 \\
11.39 * *\end{array}$ & $\begin{array}{c}5.11 \\
11.72 * * *\end{array}$ & $\begin{array}{c}5.05 \\
12.22 * * *\end{array}$ & $\begin{array}{c}5.09 \\
12.30 * * *\end{array}$ \\
\hline LnBOMET & $\begin{array}{l}-0.29 \\
-1.25\end{array}$ & $\begin{array}{l}-0.30 \\
-1.33\end{array}$ & $\begin{array}{l}-0.33 \\
-1.51\end{array}$ & $\begin{array}{l}-2.05 \\
-1.01\end{array}$ & $\begin{array}{l}-0.20 \\
-0.98\end{array}$ \\
\hline TPS & $\begin{array}{l}0.01 \\
1.49\end{array}$ & & & & \\
\hline LS & & $\begin{array}{c}-0.08 \\
-3.81 * * *\end{array}$ & & & \\
\hline SLS & & & $\begin{array}{c}0.07 \\
2.07 * *\end{array}$ & & \\
\hline $\mathrm{RS}$ & & & & $\begin{array}{c}1.29 \\
3.04 * * *\end{array}$ & \\
\hline DS & & & & & $\begin{array}{c}-0.05 \\
-3.50 * * *\end{array}$ \\
\hline LnAsset & $\begin{array}{c}0.28 \\
2.93 * *\end{array}$ & $\begin{array}{c}0.29 \\
2.90 * *\end{array}$ & $\begin{array}{c}0.25 \\
2.54 * *\end{array}$ & $\begin{array}{c}0.28 \\
3.27^{* * * *}\end{array}$ & $\begin{array}{c}0.31 \\
3.50 * * *\end{array}$ \\
\hline Profitability & $\begin{array}{l}0.29 \\
0.57\end{array}$ & $\begin{array}{l}0.21 \\
0.42\end{array}$ & $\begin{array}{l}0.22 \\
0.45\end{array}$ & $\begin{array}{l}0.19 \\
0.44\end{array}$ & $\begin{array}{l}0.09 \\
0.20\end{array}$ \\
\hline ROA & $\begin{array}{l}0.01 \\
0.81\end{array}$ & $\begin{array}{l}0.01 \\
0.72\end{array}$ & $\begin{array}{l}0.01 \\
1.01\end{array}$ & $\begin{array}{l}0.01 \\
1.02\end{array}$ & $\begin{array}{l}0.01 \\
1.83^{*}\end{array}$ \\
\hline RISK & $\begin{array}{l}0.08 \\
0.11\end{array}$ & $\begin{array}{l}0.04 \\
0.05\end{array}$ & $\begin{array}{l}0.20 \\
0.27\end{array}$ & $\begin{array}{c}-0.44 \\
-2.04 * *\end{array}$ & $\begin{array}{c}-0.46 \\
-2.30 * *\end{array}$ \\
\hline Pension & $\begin{array}{c}-0.44 \\
-2.02 * *\end{array}$ & $\begin{array}{c}-0.46 \\
-2.32 * *\end{array}$ & $\begin{array}{l}-0.30 \\
-1.20\end{array}$ & $\begin{array}{l}-0.01 \\
-0.07\end{array}$ & $\begin{array}{l}-0.02 \\
-0.16\end{array}$ \\
\hline EXCEP & $\begin{array}{l}-0.01 \\
-0.07\end{array}$ & $\begin{array}{l}-0.02 \\
-0.16\end{array}$ & $\begin{array}{l}-0.02 \\
-0.27\end{array}$ & $\begin{array}{c}-10.91 \\
-7.88 * * *\end{array}$ & $\begin{array}{c}-10.64 \\
-7.52 * * *\end{array}$ \\
\hline Intercept & $\begin{array}{c}-10.08 \\
-6.94 * * *\end{array}$ & $\begin{array}{c}-10.22 \\
-6.98 * * *\end{array}$ & $\begin{array}{c}-9.84 \\
-6.79 * * *\end{array}$ & $\begin{array}{c}-10.91 \\
-7.88 * * *\end{array}$ & $\begin{array}{c}-10.64 \\
-7.52 * * *\end{array}$ \\
\hline $\begin{array}{l}\text { Adj } R \\
N=209\end{array}$ & 0.66 & 0.66 & 0.68 & 0.66 & 0.66 \\
\hline
\end{tabular}

Notes: BOIND is board independence; defined as the proportion of independent directors to total directors on the board. LnBOSIZE is board size; defined as the log of the total number of directors on the board. LnBOMET is Board meeting; defined as the log of the total number of meetings held in a year. TPS is total percentage shareholding of all shareholders with at least $3 \%$ of the total shareholdings in a firm. LS is largest shareholder and is the shareholder with the highest shareholding in a firm. SLS is the second largest shareholder and is the shareholder with the next largest shareholdings in a firm. RS is the ratio of shareholding and is the ratio of the shareholding of the second largest to the largest shareholder. DS is the difference in shareholding and is difference between the shareholding of the largest to the second largest shareholder. LnAsset is the log of total asset and proxy for firm size. Profitability is a dummy variable, 1 if firm reports profit in the last three years and 0 if otherwise. ROA is return on Assets and is a proxy for firm efficiency in asset utilization; defined as the ratio of total profit before tax divided by capital employed. RISK proxy for firm riskiness and is the sum of total inventory and receivables divided by total asset. Pension is a measure of complexities and it is 1 if a firm reports pension cost figures and 0 if otherwise. EXCEP is a measure of complexities and it is 1 if a firm reports exceptional item in the year and 0 if otherwise. $*=$ significant at 0.1 level, i.e., $\mathrm{p}<0.10 ; * *=$ significance at 0.05 level, i.e., $\mathrm{p}<0.05 ; * * *=$ significance at 0.01 level, i.e., $\mathrm{p}<0.01$. 


\subsubsection{Audit committee effects}

Although Beasley (1996) argue that the board rather than the audit committee are crucial for corporate monitoring, it is also reasonable to argue that the board is dependent on the board level committees and especially the audit committees. This study assuages the concern that lack of control for audit committee activity may affect the result, by conducting additional analysis. The study includes some measures of audit committees into the regression model because it is by far the most prominent board level committee. The study included measure of audit committee size and audit committee meeting frequency into the main regression models. The study finds that the results remain largely unchanged and are identical to the main results reported in Table 4. This supports the view by Beasley (1996) and Klein (2002) that the board is primarily charged with the overall board monitoring and oversight function on the management and not the audit committee, which may be more focused on auditing and reporting functions of the firm.

\section{Summary and conclusions}

This study examines the relationship between MLSs and BOIND. The investigation is important against the backdrop of growing attention from policy makers and regulators on the most appropriate composition of the board of directors that will enhance the protection of shareholders' interests. The recent financial crisis and previous corporate governance failures remain suspect for these heightened concerns. The literature has copious evidence showing that investors with large stakes in listed firms have the incentives and resources to monitor management and thereby enhance the protection of shareholders' interests against exploitation by management. However, the literature is scanty on the impact of the interactions between large owners on BOIND. While the extant literature has focused more on the internal determinants of board composition, limited studies exist on the effects of MLS on BOIND. This is despite the potential for this ownership structure to enhance the monitoring roles of large shareholders and thereby improve board oversight functions, which could enhance firm performance.

This study tested six interlinked hypotheses to answer the following related questions; Firstly, does the presence of MLSs facilitate BOIND or not? Secondly, what is the relationship between the size of the shareholding by the LS and BOIND? Lastly, does the presence of a SLS in a MLS affect BOIND? The results of the hypotheses testing show that a significant negative relationship exists between ownership by LS and BOIND. This indicates that LS prefers a less independent board. A board that has higher proportion of insider directors compared to outside independent directors is more likely to facilitate the consumption of private benefits and to enable expropriation of a firm's resources, than an independent board.

The study also finds a significant positive relationship between the size of the shareholding of the SLS and BOIND. This is consistent with the perception that the presence of a SLS could act as check on the behaviour of the LS. This ownership situation could lead to improved corporate governance mechanism within the firm since both shareholders may ultimately agree to bind themselves to a higher corporate governance level. This will be necessary to avoid the adverse consequences of control contest or disagreements between large owners, which may adversely affect firm value. They could therefore resolve to an independent board which, all things being equal, could 
protect the interests of all shareholders against opportunistic behaviours by large shareholders and management. However, the effectiveness of this monitoring by the second largest owner is dependent on the extent of the difference in the ownership of the first relative to the ownership of the second largest owner in the firm.

The study finds a significant positive relationship between the ratio of the shareholding of the second relative to first LS and BOIND. This suggests that the higher the relative shareholding of the SLS to the first LS, the higher the propensity for a board to be independent. The study also finds a significant negative relationship between the difference in the shareholding of the LS and the SLS and BOIND. This is consistent with the perception that the higher the difference in their ownership, the lower the propensity for a board to be independent due to the increasing influence of the LS relative to the SLSs. This finding indicates that value adding corporate governance ensured by an independent board is attainable through ownership structure that facilitate the presence of a second largest owner, whose ownership stake in the firm is such that allows it to performance oversight on the activities of the first largest owner. This is particularly relevant to the regulator as it provides a veritable policy option to work with in respect of firm ownership configuration that could enhance corporate governance and the protection of the interest of other shareholders; those with very small stakes in the firm. These findings also complement findings from earlier studies regarding corporate governance mechanism complementarity. The study shows that ownership configuration and BOIND are examples of corporate governance mechanisms that are interlinked. The presence of a second largest owner facilitates the emergence of an independent board. This board structure is capable of protecting the interest of the firm and preserving firm value by preventing corporate expropriation. The findings in this study are important for many stakeholders in the corporate environment. Apart from those already highlighted earlier in respect of the regulators, one additional implication of our findings is that minority shareholders should be aware of the likelihood of collusion and competition amongst large shareholders and how this could impact on their own stake and position in the company. This is important in terms of the decision to continue to hold investment in a firm or exit. In this sense, our findings and existing literature suggest that competition and rivalry amongst large owners is potentially a good sign for corporate transparency and firm value.

This study has a number of limitations. Firstly, a longitudinal study may provide more clarity on the issues addressed. However, the study notes that ownership structure and board composition are sticky and do not change often. The study avoided the potential bias in the investigation that may arise by using data in the period running up to and during the financial crisis. Future studies may wish to explore ownership dynamics in this period and their effects on board compositions. Such studies could explore the implications of the financial crisis for the interactions between multiple large owners for example, regarding risk management. This line of inquiry will be useful to highlight the role of ownership contest or coalition in risk management. Future studies may also explore this type of ownership structure in developing economies where information asymmetry may be more pronounced and where ownership characteristics are different to those in this study. Therefore our findings are limited and applicable in firms operating under similar context to those used in this study. In this sense, whilst our results are applicable to large listed firms, it may not be applicable to other corporate structures. Furthermore, the study acknowledges that outcomes from research into ownership and their impacts on various aspects of the activities of the firm may vary across jurisdictions. 
The study therefore recommends more country-specific analysis in addition to the growing cross-country analyses.

\section{References}

Adams, R.B., Hermalin, B.E. and Weisbach, M.S. (2010) 'The role of boards of directors in corporate governance: a conceptual framework and survey', Journal of Economic Literature, Vol. 48, No. 1, pp.58-107.

Adkins, L.C. and Hill, R.C. (2011) Using STATA for Econometrics, 4th ed., Wiley, Hoboken, NJ.

Admati, A.R., Pfleiderer, P. and Zechner, J. (1994) 'Large shareholder activism, risk sharing, and financial market equilibrium', Journal of Political Economy, Vol. 102, No. 6, pp.1097-1130.

Agrawal, A. and Mandelker, G.N. (1990) 'Large shareholders and the monitoring of managers: the case of antitakeover charter amendments', Journal of Financial and Quantitative Analysis, Vol. 25, No. 2, pp.143-161.

Aguilera, R.V., Filatotchev, I., Gospel, H. and Jackson, G. (2008) 'An organizational approach to comparative corporate governance: costs, contingencies, and complementarities', Organization Science, Vol. 19, No. 3, pp.475-492.

Al-Bassam, W.M., Ntim, C.G., Opong, K.K. and Downs, Y. (2015) 'Corporate boards and ownership structure as antecedents of corporate governance disclosure in Saudi Arabian publicly listed corporations', Business and Society, DOI: 0007650315610611.

Al-Najjar, B. (2017) 'Corporate governance and CEO pay: evidence from UK travel and leisure listed firms', Tourism Management, Vol. 60, pp.9-14.

Anderson, R.C. and Reeb, D.M. (2004) 'Board composition: balancing family influence in S\&P 500 firms', Administrative Science Quarterly, Vol. 49, No. 2, pp.209-237.

Anderson, R.C., Mansi, S.A. and Reeb, D.M. (2004) 'Board characteristics, accounting reporting integrity and cost of debt', Journal of Accounting and Economics, Vol. 37, No. 3, pp.315-342.

Attig, N., Guedhami, O. and Mishra, D. (2008) 'Multiple large shareholders, control contests, and implied cost of equity', Journal of Corporate Finance, Vol. 14, No. 5, pp.721-737.

Balsam, S., Bartov, E. and Marquardt, C. (2002) 'Accrual, management, investor sophistication, and equity valuation: evidence from 10Q fillings', Journal of Accounting Research, Vol. 40, No. 4, pp.987-1012.

Bazerman, M., Morgan, K. and Loewenstein, G. (1997) 'The impossibility of auditor Independence', Sloan Management Review, Vol. 88, No. 4 pp.98-94.

Beasley, M. (1996) 'An empirical analysis of the relation between the board of director composition and financial statement fraud', Accounting Review, Vol. 71, No. 4, pp.443-465.

Bennedsen, M. and Wolfenzon, D. (2000) 'The balance of power in closely held corporations', Journal of Financial Economics, Vol. 58, No. 1, pp.113-139.

Bhagat, S. and Black, B.S. (2002) 'The non-correlation between board independence and long-term firm performance', Journal of Corporation Law, Vol. 27, pp.231-273.

Black, B.S. (1990) 'Shareholder passivity re-examined', Michigan Law Review, Vol. 89, No. 3, pp.520-608.

Black, B.S., Jang, H. and Kim, W. (2006) 'Predicting firms' corporate governance choices: evidence from Korea', Journal of Corporate Finance, Vol. 12, No. 3, pp.660-691.

Boone, A.L., Field, L.C., Karpoff, J.M. and Raheja, C.G. (2007) The determinants of corporate board size and composition: an empirical analysis', Journal of Financial Economics, Vol. 85, No. 1, pp.66-101.

Brick, I.E. and Chidambaran, N.K. (2010) 'Board meetings, committee structure, and firm value', Journal of Corporate Finance, Vol. 16, No. 4, pp.533-553. 
Brickley, J.A., Lease, R.C. and Smith, C.W. (1988) 'Ownership structure and voting on antitakeover amendments', Journal of Financial Economics, Vol. 20, No. 1, pp.267-291.

Cadbury, S.A. (1992) Report of the Committee on the Financial Aspects of Corporate Governance, Gee Ltd. (Professional Publishing Ltd), London.

Caplan, B. (2001) 'Rational ignorance versus rational irrationality', Kyklos, Vol. 54, No. 1, pp.3-26.

Carcello, J.V., Hermanson, D.R. and Neal, T.L. (2002) 'Disclosures in audit committee charters and reports', Accounting Horizons, Vol. 16, No. 4, pp.291-304.

Carcello, J.V., Hermanson, D.R. and Ye, Z. (2011) 'Corporate governance research in accounting and auditing: insights, practice implications, and future research directions', Auditing: A Journal of Practice and Theory, Vol. 30, No. 3, pp.1-31.

Cheng, S. and Firth, M. (2005) 'Ownership, corporate governance and top management pay in Hong Kong', Corporate Governance: An International Review, Vol. 13, No. 2, pp.291-302.

Chenhall, R.H. and Moers, F. (2007) 'The issue of endogeneity within theory-based, quantitative management accounting research', European Accounting Review, Vol. 16, No. 1, pp.173-196.

Coffee, J.C. (1991) 'Liquidity versus control: the institutional investor as corporate monitor', Columbia Law Review, Vol. 91, No. 6, pp.1277-1368.

Dahya, J., Dimitrov, O. and McConnell, J.J. (2008) 'Dominant shareholders, corporate boards, and corporate value: a cross-country analysis', Journal of Financial Economics, Vol. 87, No. 1, pp.73-100.

Doidge, C., Karolyi, G.A. and Stulz, R.M. (2004) 'Why are foreign firms listed in the US worth more?', Journal of Financial Economics, Vol. 71, No. 2, pp.205-238.

Durnev, A. and Kim, E.H. (2005) 'To steal or not to steal: firm attributes, legal environment, and valuation', Journal of Finance, Vol. 60, No. 3, pp.1461-1493.

Earle, J.S., Kucsera, C. and Telegdy, Á. (2005) 'Ownership concentration and corporate performance on the Budapest stock exchange: do too many cooks spoil the goulash?', Corporate Governance: An International Review, Vol. 13, No. 2, pp.254-264.

Edmans, A. and Manso, G. (2009) Governance through Exit and Voice: A Theory of Multiple Large Owners, Research Paper, Institute for Law and Economics, University of Pennsylvania, Nos. 8-9.

Eisenberg, T., Sundgren, S. and Wells, M.T. (1998) 'Larger board size and decreasing firm value in small firms', Journal of Financial Economics, Vol. 48, No. 1, pp.35-54.

Eisenhardt, K.M. (1989) 'Agency theory: an assessment and review', Academy of Management Review, Vol. 14, No. 1, pp.57-74.

Erkens, D.H., Hung, M. and Matos, P. (2012) 'Corporate governance in the 2007-2008 financial crisis: evidence from financial institutions worldwide', Journal of Corporate Finance, Vol. 18, No. 2, pp.389-411.

Faccio, M. and Lasfer, M.A. (2000) 'Do occupational pension funds monitor companies in which they hold large stakes?', Journal of Corporate Finance, Vol. 6, No. 1, pp.71-110.

Fama, E.F. (1980) 'Agency problems and the theory of the firm', Journal of Political Economy, Vol. 88, No. 2, pp.288-307.

Fama, E.F. and Jensen, M.C. (1983) 'Separation of ownership and control', The Journal of Law and Economics, Vol. 26, No. 2, pp.301-325.

Gianfrate, G. (2007) 'What do shareholders' coalitions really want? Evidence from Italian voting trusts', Corporate Governance: An International Review, Vol. 15, No. 2, pp.122-132.

Gomes, A. and Novaes, W. (2006) Sharing of Control Versus Monitoring as Corporate Governance Mechanisms, Working Paper, Washington University, St. Louis.

Grossman, S.J. and Hart, O.D. (1980) 'Takeover bids, the free-rider problem, and the theory of the corporation', The Bell Journal of Economics, Vol. 11, No. 1, pp.42-64.

Guest, P.M. (2008) 'The determinants of board size and composition: evidence from the UK', Journal of Corporate Finance, Vol. 14, No. 1, pp.51-72. 
Hair, J.F., Black, W.C., Babin, B.J. and Anderson, R.E. (2010) Multivariate Data Analysis: A Global Perspective, Prentice Hall, Upper Saddle River, NJ.

Hann, R.N. Heflin, F. and Subramanayam, K.R. (2007) 'Fair-value pension accounting', Journal of Accounting and Economics, Vol. 44, No. 3, pp.328-358.

Hentschel, L. and Kothari, S.P. (2001) 'Are corporations reducing or taking risks with derivatives?', Journal of Financial and Quantitative Analysis, Vol. 36, No. 01, pp.93-118.

Hermalin, B.E. and Weisbach, M.S. (2003) Board of Directors as an Endogenously Determined Institution, Vol. 9, pp.1-20, Federal Reserve Bank of New York Economic Policy Review.

Hill, R.C., Griffiths, W.E. and Lim, G.C. (2012) Principles of Econometrics, 4th ed., Wiley, Hoboken, NJ.

Hillman, A.J., Cannella, A.A. and Paetzold, R.L. (2000) 'The resource dependence role of corporate directors: strategic adaptation of board composition in response to environmental change', Journal of Management Studies, Vol. 37, No. 2, pp.235-256.

Holderness, C.G. (2009) 'The myth of diffuse ownership in the United States', Review of Financial Studies, Vol. 22, No. 4, pp.1377-1408.

Jarrell, G.A. and Poulsen, A.B. (1987) 'Shark repellents and stock prices: the effects of antitakeover amendments since 1980', Journal of Financial Economics, Vol. 19, No. 1, pp.127-168.

Jensen, M.C. and Meckling, W.H. (1976) 'Theory of the firm: managerial behavior, agency costs and ownership structure', Journal of Financial Economics, Vol. 3, No. 4, pp.305-360.

Karamanou, I. and Vafeas, N. (2005) 'The association between corporate boards, audit committees, and management earnings forecasts: an empirical analysis', Journal of Accounting Research, Vol. 43, No. 3, pp.453-486.

Kaserer, C. and Moldenhauer, B. (2008) 'Insider ownership and corporate performance: evidence from Germany', Review of Managerial Science, Vol. 2, No. 1, pp.1-35.

Kim, K.A., Kitsabunnarat-Chatjuthamard, P. and Nofsinger, J.R. (2007) 'Large shareholders, board independence, and minority shareholder rights: evidence from Europe', Journal of Corporate Finance, Vol. 13, No. 5, pp.859-880.

Klein, A. (2002) 'Audit committee, board of director characteristics, and earnings management', Journal of Accounting and Economics, Vol. 33, No. 3, pp.375-400.

Knechel, W.R. and Sharma, D.S. (2012) 'Auditor-provided nonaudit services and audit effectiveness and efficiency: evidence from pre-and post-SOX audit report lags', Auditing: A Journal of Practice and Theory, Vol. 31, No. 4, pp.85-114.

Koh, P. S. (2007) 'Institutional investor type, earnings management and benchmark beaters', Journal of Accounting and Public Policy, Vol. 26, No. 3, pp.267-299.

La Porta, R., Lopez-de-Silanes, F., Shleifer, A. and Vishny, R. (2002) 'Investor protection and corporate valuation', The Journal of Finance, Vol. 57, No. 3, pp.1147-1170.

Laeven, L. and Levine, R. (2007) 'Complex ownership structures and corporate valuations', The Review of Financial Studies, Vol. 21, No. 2, pp.579-604.

Landsman, W.R., and Ohlson, J.A. (1990) 'Evaluation of market efficiency for supplementary accounting disclosures: the case of pension assets and liabilities', Contemporary Accounting Research, Vol. 7, No. 1, pp.185-198.

Larcker, D.F. and Rusticus, T.O. (2007) 'Endogeneity and empirical accounting research', European Accounting Review, Vol. 16, No. 1, pp.207-215.

Larcker, D.F. and Rusticus, T.O. (2010) 'On the use of instrumental variables in accounting research', Journal of Accounting and Economics, Vol. 49, No. 3, pp.186-205.

Lee, H.Y. and Mande, V. (2005) 'The relationship of audit committee characteristics with endogenously determined audit and non-audit fees', Quarterly Journal of Business and Economics, Vol. 44, Nos. 3/4, pp.93-112. 
Lehmann, E. and Weigand, J. (2000) 'Does the governed corporation perform better? Governance structures and corporate performance in Germany', Review of Finance, Vol. 4, No. 2, pp.157-195.

Lehn, K., Patro, S. and Zhao, M. (2004) Determinants of the Size And Structure of Corporate Boards: 1935-2000, Unpublished Working Paper, University of Pittsburgh.

Li, J., Mangena, M. and Pike, R. (2012) 'The effect of audit committee characteristics on intellectual capital disclosure', The British Accounting Review, Vol. 44, No. 2, pp.98-110.

Li, J., Pike, R. and Haniffa, R. (2008) 'Intellectual capital disclosure and corporate governance structure in UK firms', Accounting and Business Research, Vol. 38, No. 2, pp.137-159.

Lipton, L. and Lorsch, J. (1992) 'A modest proposal for improved corporate governance', The Business Lawyer, Vol. 48, pp.59-77.

Luo, J.H., Wan, D.F., Cai, D. and Liu, H. (2013) 'Multiple large shareholder structure and governance: the role of shareholder numbers, contest for control, and formal institutions in Chinese family firms', Management and Organization Review, Vol. 9, No. 2, pp.265-294.

Magee, S.P., Brock, W.A. and Young, L. (1989) Black Hole Tariffs and Endogenous Policy Theory: Political Economy in General Equilibrium, Cambridge University Press, Cambridge.

Mallin, C.A. (2004) Corporate Governance, Oxford University Press, Oxford.

Maug, E. (1998) 'Large shareholders as monitors: is there a trade-off between liquidity and control?', The Journal of Finance, Vol. 53, No. 1, pp.65-98.

Maury, B. and Pajuste, A. (2005) 'Multiple large shareholders and firm value', Journal of Banking \& Finance, Vol. 29, No. 7, pp.1813-1834.

McCahery, J.A., Sautner, Z. and Starks, L.T. (2016) 'Behind the scenes: the corporate governance preferences of institutional investors', The Journal of Finance, Vol. 71, No. 6, pp.2905-2932.

McConnell, J.J. and Servaes, H. (1990) 'Additional evidence on equity ownership and corporate value', Journal of Financial Economics, Vol. 27, No. 2, pp.595-612.

Ntim, C.G. (2013) 'Corporate ownership and market valuation in South Africa: uncovering the effects of shareholdings by different groups of corporate insiders and outsiders', Int. J. Business Governance and Ethics, Vol. 8, No. 3, pp242-264.

Pagano, M. and Röell, A. (1998) 'The choice of stock ownership structure: agency costs, monitoring, and the decision to go public', The Quarterly Journal of Economics, Vol. 113, No. 1, pp.187-225.

Pearce, J.A. and Zahra, S.A. (1992) 'Board composition from a strategic contingency perspective', Journal of Management Studies, Vol. 29, No. 4, pp.411-438.

Rediker, K.J. and Seth, A. (1995) 'Boards of directors and substitution effects of alternative governance mechanisms', Strategic Management Journal, Vol. 16, No. 2, pp.85-99.

Roe, M.J. (1990) 'Political and legal restraints on ownership and control of public companies', Journal of Financial Economics, Vol. 27, No. 1, pp.7-41.

Rosenstein, S. and Wyatt, J.G. (1997) 'Inside directors, board effectiveness, and shareholder wealth', Journal of Financial Economics, Vol. 44, No. 2, pp.229-250.

Shleifer, A. and Vishny, R.W. (1997) 'A survey of corporate governance', The Journal of Finance, Vol. 52, No. 2, pp.737-783.

Shleifer, A. and Vishny, R.W. (1986) 'Large shareholders and corporate control', Journal of Political Economy, Part 1, Vol. 94, No. 3, pp.461-488.

Short, H. and Keasey, K. (1999) 'Managerial ownership and the performance of firm: evidence from the UK', Journal of Corporate Finance, Vol. 5, No. 1, pp.79-101.

Solomon, J. (2010) Corporate Governance and Accountability, 3rd ed., John Wiley and Sons, Chichester. 
Sur, S., Lvina, E. and Magnan, M. (2013) 'Why do boards differ? Because owners do: assessing ownership impact on board composition', Corporate Governance: An International Review, Vol. 21, No. 4, pp.373-389.

Sykes, T. (1994) The Bold Riders: Behind Australia's Corporate Collapses, St Leonards, NS.

Thomsen, S., Pedersen, T. and Kvist, H.K. (2006) 'Blockholder ownership: effects on firm value in market and control based governance systems', Journal of Corporate Finance, Vol. 12, No. 2, pp.246-269.

Vafeas, N. (1999) 'Board meeting frequency and firm performance', Journal of Financial Economics, Vol. 53, No. 1, pp.113-142.

Velury, U. and Jenkins, D.S. (2006) 'Institutional ownership and the quality of earnings', Journal of Business Research, Vol. 59, pp.1043-1051.

Villalonga, B. and Amit, R. (2006) How do family ownership, control and management affect firm value?', Journal of Financial Economics, Vol. 80, No. 2, pp.385-417.

Wang, M. and Hussainey, K. (2013) 'Voluntary forward-looking statements driven by corporate governance and their value relevance', Journal of Accounting and Public Policy, Vol. 32, No. 3, pp. 26-49.

Wang, Z. (2017) 'Turf war or collusion: an empirical investigation of conflict of interest between large shareholders', Corporate Governance: An International Review, Vol. 25, No. 5, pp.358-380

Ward, A.J., Brown, J.A. and Rodriguez, D. (2009) 'Governance bundles, firm performance, and the substitutability and complementarity of governance mechanisms', Corporate Governance: An International Review, Vol. 17, No. 5, pp.646-660.

Whisenant, S., Sankaraguruswamy, S. and Raghunandan, K. (2003) 'Evidence on the joint determination of audit and non-audit fees', Journal of Accounting Research, Vol. 41, No. 4, pp.721-744.

Wooldridge, J.M. (2008) Introductory Econometrics: A Modern Approach, 4th ed., Cengage Learning, Mason, $\mathrm{OH}$.

Yermack, D. (1996) 'Higher market valuation of companies with a small board of directors', Journal of Financial Economics, Vol. 40, No. 2, pp.185-211.

\section{Notes}

1 We used board structure and composition interchangeably to refer to whether the board is independent or not.

2 In the UK, the identity and shareholding of shareholders with up to $3 \%$ or more of the total issued shares of a listed company must be disclosed.

3 These concerns became heightened due to the corporate governance and recent financial crises. The Sarbanes Oxley Act in the US and the UK's corporate governance codes amongst other countries have expressed clear expectations regarding the role of the board in corporate governance and also the increasing role of the large shareholders including institutional investors (see Adams et al., 2010; Sur et al., 2013).

4 FAME stands for financial analysis made easy and it is a depository of financial and company information covering over 2 million public and private companies in the UK and Ireland. More information about the database can be accessed from the website http://www.bvdinfo.com/Products/Company-Information/National/FAME.aspx?gclid= CMTG352V-q0CFSgntAodNEkUuA

5 The study recognises the fact that control contest can be counterproductive, for example, if a large owner decides to exit the firm this may lead to herding behaviour amongst investors, eventually resulting in reduced firm value. 
6 Endogeneity is where there is violation of the classical ordinary least square assumption of no correlation between the explanatory variable and the error term (Hill et al., 2012; Wooldridge, 2008). Such violation leads to inconsistent estimate of the parameters and could lead to spurious regression outcomes (Hill et al., 2012; Wooldridge, 2008). Endogeneity may be due to a number of reasons including measurement error, wrong model specification and simultaneity bias.

7 We used STATA software version 8 for this test.

8 The instrumental variable or the two stage least square approach requires the identification of a variable $(Z)$ that is sufficiently correlated with the suspected endogenous variable $(X)$ but which is not correlated with the error term(U). In the first stage, the endogenous variable is regressed on the instrumental variable and other exogenous variables in the model and the fitted value from this regression is used as an exogenous variable along with the other exogenous variables in the second stage regression with the original dependent variable. The coefficient obtain from this regression will be proper and unbiased estimates of the parameters (Hill et al., 2012; Wooldridge, 2008).

9 To generate this in STATA we used the egen command for example we used egen RANK = rank (TPS). 